\title{
The Impact of Fiscal and Monetary Shock on Economic Activity in Serbia: SVAR Approach
}

\author{
Article history: \\ Received: 3 March 2017 \\ Sent for revision: 28 March 2017 \\ Received in revised form: 28 April 2017 \\ Accepted: 3 May 2017 \\ Available online: 1 July 2017
}

\begin{abstract}
Contribution of fiscal policy to macroeconomic stabilization is significant. The main objective of this article is to assess the impact of fiscal and monetary shock to macroeconomic variables in Serbia in period between the years 2007-2016. This period covers the implementation of inflation targeting strategy in Serbia with the main goal of monetary policy is price stability. One of the biggest concerns in inflation targeting framework is fiscal discipline. In research is implemented structural vector autoregression. The results showed that both fiscal and monetary shocks affect Serbian economy.
\end{abstract}

Keywords: fiscal and monetary shock, structural vector autoregression, inflation targeting, macroeconomic stability

\section{Uticaj fiskalnog i monetarnog šoka na ekonomsku aktivnost u Srbiji, SVAR pristup}

Apstrakt: Doprinos fiskalne politike makroekonomskoj stabilizacije je značajan. Glavni cilj ovog rada jeste da se oceni uticaj fiskalnog šoka $i$ monetarnog šoka na makroekonomse varijable u Srbiji u periodu izmeđtu 2007-2016. Godine. Ovaj period pokiriva primenu strategiju ciljanja inflacije u Srbiji čiji je glavni cilj očuvanje cenovne stabilnosti. Jedna od najvećih pitanja u okviru ciljanja inflacije jeste fiskalna disciplina. U istraživanju primenjena je metodologije strukturne vektorske autoregresije. Rezultati su pokazali da fiskalni i moneterni šokovi utiču na Srpsku privredu.

\footnotetext{
${ }^{1}$ Economics Institute, Belgrade, sabung@gmail.com 
Bungin S.: The Impact of Fiscal and Monetary Shock on Economic Activity in Serbia...

Ključne reči: fiskalni i monetarni šok, strukturna vektorska autoregresije, ciljanje inflacije, makroekonomska stabilnost

\section{Introduction}

Fiscal policy has been always an issue regarding macroeconomic stability in Serbia. Since the period of hyperinflation which was caused by large government spending during the nighties, public has always been aware of dangers of fiscal indiscipline. In inflation targeting framework, coordination between fiscal and monetary policy is essential. It is also determined by Agreement between the National Bank of Serbia and the Government on Inflation Targeting. As it is wide known from economic theory, increase in government expenditures cause growth of aggregate demand greater than aggregate supply, and consequently inflation rise. In the past decade, fiscal authorities in Serbia have been fighting with constant fiscal deficit, as well as high public debt. In such circumstances, keeping current inflation within the targeted bounds has been a challenge. During the transition period, as it is the case in most countries that experienced the path of transition, size of government in the local economy is very significant, and therefore some fiscal discipline has to be conducted.

Having in mind limited scope of monetary policy in macroeconomic stabilization, fiscal policy is very important tool in overcoming the business cycles. Fiscal policy can contribute to macroeconomic stability by limiting aggregate demand and private sectors incomes during the economic slowdown. On the other hand, in times of economic growth, fiscal policy can control rising economic activity. One of the channels that fiscal policy contributes to macroeconomic stability is so called automatic fiscal stabilizers. These stabilizers represents automatic impact in government budget during the economic cycles and do not require any policy making short term decisions. Another channel is discretionary fiscal policy, where government adjusts spending or taxes as the respond to the current economic circumstances. Automatic stabilizers are short run policy, while discretionary fiscal policy is preferable in long run scope where government needs to develop some structural changes in public finances and to act according to some unexpected fluctuations.

Having in mind different approaches that analyse the impact of we can distinguish New Keynesian and Neoclassical view. The first propagate that unexpected rise in government expenditure cause rise in aggregate and labor demand, leading to consumption and salary growth. The Neoclassical approach consider that government spending reduce wealth since the its growth leads to rises in taxes, which reduces consumption and lowers the 
Bungin S.: The Impact of Fiscal and Monetary Shock on Economic Activity in Serbia...

need for labor. Government spending in both theories stimulates economic growth and contributes to GDP increase.

In most of the literature there is a view of existence expected inflation channel regarding government spending, due to rising consumption, which is in accordance to New Keynesian theory. Within this channel, government spending boosts current and expected real wages. In case where business sector may be unable to change its prices for some time, increase in expected real wages leads to higher demand and consequently to price increase at the present (Dupor at all 2013). This is effect is predominantly significant when monetary authorities don't implement restrictive monetary policy by increasing reference rate.

In this paper will be analyzed effect of fiscal and monetary shock on real variables in Serbia in the period 2007-2016 that covers inflation targeting framework. The model used in econometric testing is structural vector autoregression which is recommended by Blanchard and Perotti (1999). This is most common model used to test fiscal shock in small open economy. There will be represent the conclusions regarding impact of unexpected rise of government expenditure and short term interest rate on GDP, inflation and interest rate.

\section{Literature review}

One of the most common approaches for estimating fiscal policy shock using SVAR methodology is Blanchard and Perotti (1999).

This paper analyzes the impact government spending shocks and taxes on economic activity. The results presented that increase in government spending increase output, while increase in taxes has negative effect. Another conclusion is that "both increases in government spending have a strong negative effect on investment spending".

Other studies that are to fiscal shocks are Perotti (2002), that investigates effect of fiscal policy on GDP, inflation and interest rates in 5 OECD countries using SVAR approach. Gali at all, (2004) using quarterly US data, finds an increase in consumption in response to government spending.

From the studies that are related to European data, we can distinguish study of Giordano et al. (2005) that is related to Italian fiscal policy. Authors apply Blanchard-Perotii methodology, using six variables VAR model which includes private GDP, the private GDP deflator, employment, the real interest rate, direct expenditure and net revenue. Authors find that government spending increase output. Shock has very limited duration than those investigated on 
Bungin S.: The Impact of Fiscal and Monetary Shock on Economic Activity in Serbia...

US data. Moreover, the reaction of output after the shock is relatively weak and diminished quite fast.

De castro at all (2008) using SVAR methodology for Spanish data finds that government spending can stimulate economic activity, but the side effects are higher inflation, public deficit and lesser output. Heppke-Falk at all (2006) finds that positive fiscal shock cause an output growth. Authors also find that increase in government revenues does not stimulate output. Consumption responds weakly to increase in fiscal spending, whereas investment reacts more significantly.

Baxa (2010) presents results that are related do Czezh data, and finds that the shocks to government expenditures have a significant positive impact on GDP whereas the impact of the changes in government revenues is rather insignificant. Mirdala (2009) estimated VAR methodology for the six countries with goal to investigate the fiscal shock impact on in Czech Republic, Hungary, Poland, the Slovak republic, Bulgaria and Romania. Author finds that there is a most significant response of real output in Bulgaria, while it is followed by Czech Republic. There is reasonable output growth in Hungary and the Slovak Republic. Considering Poland and Romania, there is a delay of positive fiscal shock on output.

Ravnik and Zilic (2012) use the Blanchard-Perotti method for the identification of a structural vector autoregressive model in a disaggregated analysis of the macroeconomic effects of fiscal policy shocks for the case of Croatia. The presented results showed fiscal shock reduces inflation in short run, while interest rate increases. Regarding Serbia, paper by Rakic and Radjenovic (2013) analyse the impact of fiscal and monetary policy on economic activity. Results showed that monetary policy variables stimulate economic growth, while fiscal policy doesn't have significant effect on real economy.

\section{Some Features of Fiscal and Monetary Policy in Serbia}

Serbia has quite long history of monetary expansion. Since the 90ties when fiscal expansion created hyperinflation spiral, conduct of monetary policy has always been under the pressure of fiscal authorities. After the democratic changes in 2000, high inflation was reduced by putting under the controls the exchange rate fluctuations. High capital inflows as result of privatization process caused fast economic growth and rise of domestic demand. In the period 2000-2008, Serbia had procyclical fiscal policy which means that in good times when fiscal revenues where above the average, government created fiscal deficit which was financed by privatization revenues (USAID at all, 2010). Strong economic growth led to increase of tax base, which triggered the fiscal authorities to cut some taxes while increasing the 
Bungin S.: The Impact of Fiscal and Monetary Shock on Economic Activity in Serbia...

government spending. Global financial crisis had a great influence in sudden decrease of capital inflows in Serbia. Decrease of domestic demand caused drop of economic activity and therefore government revenues, while public sector expenditures still remain at the same level. Such policy headed to high public debt of $45 \%$ of GDP which was to clear sign for the fiscal consolidation. The first attempt of fiscal consolidation and structural reforms was unsuccessful that led to canceling the agreement with IMF. The next attempt of fiscal consolidation came with a new government in 2012, and it was also characterized as quite unsuccessful. The new three year program of fiscal consolidation that started at the end of 2014 delivered decrease of budget deficit, as a cause of increase of non-tax government revenues and delaying public investments. Part of lower deficit is also a result of structural changes and decrease of wages in public sector and pension expenditures. Also, unexpected good public revenue collection contributed to success of current fiscal consolidation in Serbia (Fiscal Council of Republic of Serbia, 2015). The following table shows some of the main macroeconomic indicators.

Table 1. The Serbian macroeconomic data

\begin{tabular}{|l|c|c|c|c|c|}
\hline Macroeconomic data & $\mathbf{2 0 0 6}$ & $\mathbf{2 0 0 9}$ & $\mathbf{2 0 1 2}$ & $\mathbf{2 0 1 5 .}$ & $\mathbf{2 0 1 6}$ \\
\hline Real growth of GDP (\%) & 4,9 & $-3,1$ & $-1,0$ & 0,74 & 2,7 \\
\hline $\begin{array}{l}\text { Consumer prices (in \% } \\
\text { compared to the same } \\
\text { month of the previous year) }\end{array}$ & 6,6 & 6,6 & 12,2 & 1,5 & 1,6 \\
\hline $\begin{array}{l}\text { Budget surplus/deficit on } \\
\text { republic level surplus/deficit } \\
\text { (in \% of GDP) }\end{array}$ & $-1,7$ & $-3,2$ & $-5,9$ & $-2,9$ & $-0,2$ \\
\hline $\begin{array}{l}\text { Public debt of Republic of } \\
\text { Serbia (in \% of GDP) }\end{array}$ & 35,9 & 32,8 & 56,2 & 75,9 & 73,5 \\
\hline
\end{tabular}

Source: National Bank of Serbia

As it was case in most transition countries, exchange rate has a limited effect on controlling inflation volatility, and in 2009 inflation targeting was officially introduced as new monetary strategy. The main objective of National Bank of Serbia is price stability, with the reference interest rate se the main instrument of monetary policy. In the figure 1 it is represented inflation movements during inflation targeting regime.

Implementation of inflation targeting in Serbia has been a quite challenge for monetary policy makers. As preconditions for inflation targeting such as central bank independence and credibility, fiscal discipline and single nominal anchor should be fulfilled, other features of Serbian economy obscure this process. Such feature is high eurisation, where reference interest rate has restricted impact on inflation movements. When reference interest rate represents the main monetary policy instrument, than its performance in high 
Bungin S.: The Impact of Fiscal and Monetary Shock on Economic Activity in Serbia...

eurised economy is significantly limited. In such environment, changes in interest rates on local financial market are mainly guided by changes in interest rates related to euro currency. NBS pursue monetary policy with local operation on domestic market, mainly through regular actions of NBS and treasury bills, repo operations and short term euro deposits at NBS. Previous inflation targeting experience in Serbia is diverse. On the one side, by pursuing inflation targeting current inflation is reduced on one digit level, which is success comparing the period prior the strategy implementation when inflation had reached two digits level, although during 2011 and 2013 it also was two digit level. However, the characteristic of this period is current inflation frequent deviation from targeted bounds. This observation supports facts that in the period between 2009 and 2016, the current inflation was only one third of the period observed in the targeted bounds.

Figure 1. Inflation targets fluctuations of current inflation in the period 20092016

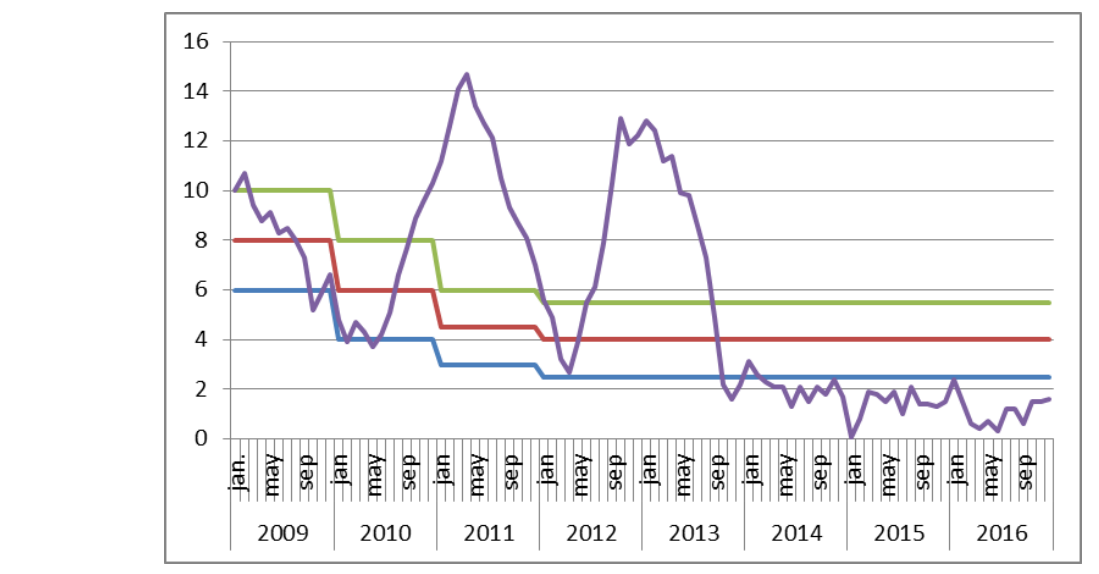

Source: National Bank of Serbia

\section{Methodology and Data}

In this paper I will use four variables SVAR which includes government spending, real GDP, consumer price index and 3-month money market interest rate Belibor.

SVAR methodology has been widely used to identify structural shock on macroeconomic variables. Basically is constructed by Sims (1980) to assess effect of monetary policy on output, and lately to investigate fiscal policy shock (Blanchard and Perotti, 1999). Main contribution of this approach is estimation of fiscal shocks that are obtained by using decision lags in policy making and 
Bungin S.: The Impact of Fiscal and Monetary Shock on Economic Activity in Serbia...

data related to the elasticity of fiscal variables to real economy, which allows to recognize the automatic reaction to changes in fiscal policy variables.

Structural VAR can be presented by following equation:

$$
A x_{t}=C(L) x_{t-1}+B \varepsilon_{t}
$$

Where A presents matrix of contemporaneous relations between variable, $x_{t}$ is a vector of the endogenous macroeconomic variables that is consisted of government spending, real GDP, CPI and three month money market interest rate, $C(L)$ is a matrix of lag length, and $B$ defines how the structural shocks influence the variables in the model.

The above equation cannot be estimated due to identification issues, so we need to estimate an unrestricted VAR of the form:

$$
X_{t}=A^{-1} C(L) x_{t-1}+A^{-1} B \varepsilon_{t}=H(L) x_{t-1}+\varepsilon_{t}
$$

In order to estimate reduced form, some restrictions need to be imposed. Economic theory can give some hints regarding the structure of the system. Therefore, we can assume the following restrictions: government spending is not contemporaneously by any shock in the variable system; real GDP is contemporaneously disturbed only by the fiscal shock; inflation react contemporaneously to fiscal and the real GDP shocks, while it is not contemporaneously affected by the interest rates shocks; interest rate is contemporaneously affected by the shocks from all the variables in the VAR.

The relationship between variables in the system can be presented in following matrix form:

$$
\left[\begin{array}{cccc}
1 & 0 & 0 & \alpha_{41} \\
\alpha_{21} & 1 & 0 & \alpha_{24} \\
\alpha_{31} & \alpha_{32} & 1 & \alpha_{34} \\
0 & 0 & 0 & 1
\end{array}\right]\left[\begin{array}{c}
u_{g d p, t} \\
u_{c p i, t} \\
u_{\text {belibor,t }} \\
u_{\text {gov_spend,t }}
\end{array}\right]=\left[\begin{array}{c}
e_{g d p, t} \\
e_{c p i, t} \\
e_{\text {belibor,t }} \\
e_{\text {gov_spend,t }}
\end{array}\right]
$$

To identify the model there has to be set limitations (Lütkepohl, 2008), that are based on economic theory. Considering that the number of endogenous variables is $\mathrm{n}=4$, according to the limitations criteria $\frac{n(n-1)}{2}$, at least 6 restrictions are imposed. 
Bungin S.: The Impact of Fiscal and Monetary Shock on Economic Activity in Serbia...

\section{Empirical Results and Discussion}

The first step in structural vector autoregressoin methodology is to determine the lag order. Number of lags is set to 1, according to SC criteria. One lag is also preferable having in mind frequency of data and relatively short time series. Model does not suffer from serial correlation and heteroscedasticity, and satisfies the normality condition. Additionally, model satisfies stability condition, since all unit roots lays in unit root circle, which is presented in the following figure.

\section{Figure 2. Stability of model}

Inverse Roots of AR Characteristic Polynomial

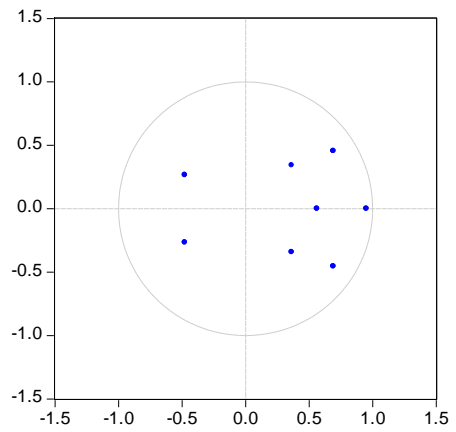

Source: authors calculation

In this case stationarity of variables is not tested, since in this kind of methodology unit root is not of such significance. Therefore all variables are tested in levels, that is usual routine in corresponding analysis (Perotti, 2002, and Heppke-Falk at all, 2006) and we are mainly interested in dynamic of shock, rather that parameters estimation.

Figure 3 shows reaction of variables to fiscal and monetary shock. Sudden increase in government spending cause a rise of real GDP in after the 6 quarters of initial fiscal shock. The effect has duration until the $10^{\text {th }}$ quarter, after the impact of shock is not any more statistically significant. This is in accordance to economic intuition of Keynesian theory. GDP reaction to monetary shock is immediate and negative. The impact monetary shock is effective until around $6^{\text {th }}$ quarter. The response of GDP is in accordance with economic intuition, where increase of interest rate lowers the investments and therefore the production. Response of CPI is not statistically significant neither to fiscal or monetary shock. On the other hand, response of interest rate on fiscal shock is also significant, where is an immediate drop of interest rates after the increase in government spending. Such finding explains somewhat 
Bungin S.: The Impact of Fiscal and Monetary Shock on Economic Activity in Serbia...

relaxed monetary policy as response to fiscal shock, since the expected reaction of short term interest rate to fiscal shock would be positive. According to variance decomposition, fiscal multiplier is rather weak, and accounts for 0,07 after four periods, and 0,63 after eight periods. Also, monetary shock account around $30 \%$ GDP variations in first quarter with the almost same value at the end of $8^{\text {th }}$ quarter. As expected, short term interest rate in high eurosied economy such as Serbian, has low explanatory power regarding the inflation variations.

Figure 3. Impulse response function
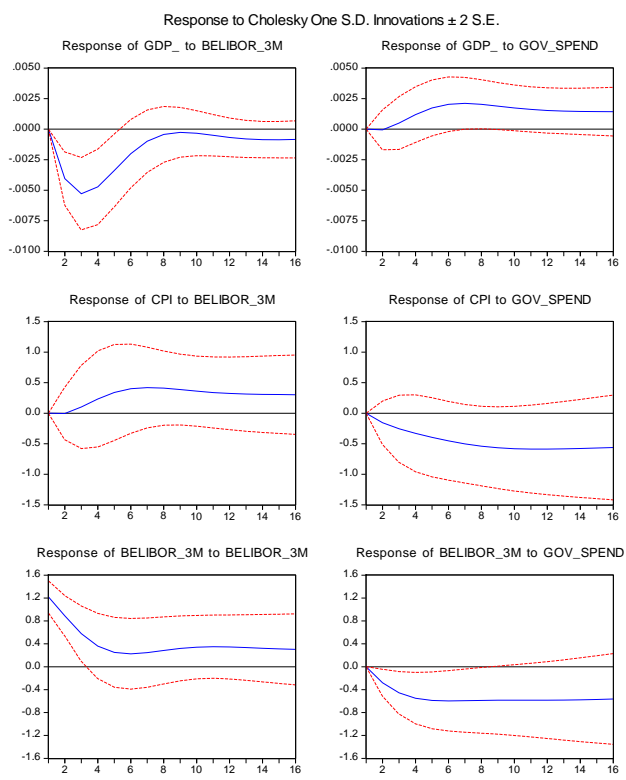

Source: author's calculation

\section{Conclusion}

In this paper is applied structural vector autoregression in order to estimate fiscal and monetary shock of short term interest rate. The results of this paper indicate the influence of fiscal policy on real GDP which supports New Keynesian view. Fiscal shock causes increase of real GDP with effect of around four quarters. The interest rate has also statistically significant influence on real output, since the increase of short term interest rate causes immediate drop of GDP and lasts around six quarters. Results also showed 
Bungin S.: The Impact of Fiscal and Monetary Shock on Economic Activity in Serbia...

that inflation is not influenced neither by interest rate nor government spending. In accordance to new Keynesian view, due to sticky prices, growth of fiscal expenditure should lead to increase of short term interest rate. The finding in this paper showed that fiscal shock influences the drop of interest rate that could be explained by rather accommodative monetary policy.

Obtained results indicate that both fiscal and monetary policy influence Serbian economy. Still, the monetary policy makers have to be focused on its main goal and that is price stability. Although results in this paper didn't showed statistically significant influence of government spending on inflation, previous experience of Serbian economy suggest that high fiscal expenditures triggers inflation rise. It is also incentive to further develop models which estimates relationships between fiscal, monetary and real variables in Serbian case.

\section{References}

Baxa, J. (2010), What the Data Say about the Effects of Fiscal Policy in the Czech Republic? In: Houda, M., Friebelova, J. (eds.): Mathematical Methods in Economics 2010. Ceske Budejovice: University of South Bohemia, 24-29.

Blanchard, O. J. and Perotti, R., (1999), An Empirical Characterization of the Dynamic Effects of Changes in Government Spending and Taxes on Output, NBER Working Paper Series, No. 7269, http://www.nber.org/papers/w7269.pdf

Bungin,S., Filipovic S., Matovic D., (2012), Carry Trade as a Speculative Investment Strategy in Serbia, Industrija, Vol. 40, No. 4, pp. 219-234 de Castro, F. and de Cos, P.

H., (2006), The Economic Effects of Exogenous Fiscal Schocks in Spain: A SVAR Approach“, Banco de Espana, Documentos de Trabajo, No 06104/2006, http://www.ecb.europa.eu/pub/pdf/scpwps/ecbwp281.pdf

Dupor, W. , Li, R. (2013). The Expected Inflation Channel of Government Spending in the Postwar U.S. Working papers, Federal Reserve Bank of St. Louis.

Fiskalni savet (2015), Fiskalna konsolidacija 2012-2014. vs. 2015-2017: ovog puta je drugačije?, http://www.fiskalnisavet.rs/doc/analize-stavovipredlozi/fiskalna_konsolidacija_2012-14_vs_2015-17.pdf

Heppke-Falk, K. H., Tenhofen, J., Wolff G. B. (2006), The Macroeconomic Effects of Exogenous Fiscal Policy Shocks in Germany: a Disaggregated SVAR Analysis, Deutsche Bundesbank Discussion Paper Series 1: Economic Studies, No 41/2006,

Lütkepohl H.,(2008), Problems Related to Over-identifying Restrictions for Structural Vector Error Correction Models, Economics Letters Vol. 99 (3), pp 512-515 http://econstor.eu/bitstream/10419/19670/1/200641dkp.pdf

Mirdala R. (2009), Effects of Fiscal Policy Shocks in the European Transition Economies. Published in: Journal of Applied Research in Finance , Vol. 1, No. 2 (December 2009): pp. 141-155

Perotti, R., 2002. "Estimating the Effects of Fiscal Policy in OECD Countries",ECB 
Bungin S.: The Impact of Fiscal and Monetary Shock on Economic Activity in Serbia...

Working Paper, No. 168.,

http://www.ecb.int/pub/pdf/scpwps/ecbwp168.pdf

Rakic, B \& Radenovic, (2013). The Effectiveness of Monetary and Fiscal Policy in Serbia, Industrija, Vol.41 No.2, pp 103-122.

Ravnik, R., Zilic, I. (2011), The Use of SVAR Analysis in Determining the Effects of Fiscal Shocks in Croatia, Financial Theory and Practice, Institute of Public Finance, Vol. 35 (1), pp. 25-58

Sims, Christopher A. 1980. "Macroeconomics and Reality," Econometrica., Vol. 48, No. 1, , pp. 1-48., DOI: 10.2307/1912017, http://www.jstor.org/stable/1912017

USAID, Ekonomski fakultet u Beogradu, Ekonomski institut (2010), Postkrizni model ekonomskog rasta i razvoja Srbije 2011-2020, http://www.kss.org.rs/doc/1102_makroekonomska_proj_razv_Srbije_20 11-2020.pdf 